\title{
Promoting Islamic Philanthropy: The Case of Sultan Qaboos Award for Voluntary Work in Oman
}

\author{
Wajeha Al-Ani \\ Department of Educational Foundations and Administration, College of Education, Sultan Qaboos University, Oman
}

\begin{abstract}
In Islamic societies, the idea of philanthropy is considered to be a backbone of the Islamic commitment towards personal and social responsibility. In order to increase people desire to promote the welfare of others and to participate effectively in voluntary work which is one of the philanthropy type of work, within this social responsibility vision, the Sultan Qaboos Award for Voluntary Work (SQAVW) was created in Oman since 2011 as one of national awards for promoting individuals, groups and institutions voluntary work. The purpose of this paper is to discuss the role of the Sultan Qaboos Award for Voluntary Work in promoting philanthropy in social development related to education. The study analyzes quantitative and qualitative data collected through closed and open-ended questionnaires from 17 participants. All participants are winners of the Sultan Qaboos Award between 2011 and 2014, and their voluntary projects are still active. The findings revealed that the Award had a vital role in motivating the respondents to participate in voluntary work (mean $=4.28$ ). The participants also stated that the winning projects were those that were creative and had a social impact and contributed to the economy. The results also pointed out that the projects had an added social value that varied according to different areas and that those related to education contributed to easing the burden of the ministry of education through the establishment of kindergartens, raising cultural and technological awareness, and enhancing the knowledge and skills of rural women and many other activities.
\end{abstract}

Keywords Islamic Philanthropy, Voluntary, Incentive, Awards

\section{Introduction}

There are several literatures on volunteerism, which based on the theory of social exchange model and Volunteer Functional Inventory VFI theory, but few are written from the Islamic perspective, this article therefore seeks to discuss volunteerism and philanthropy from the Islamic Perspective, and how the national incentive award can activate volunteer work in the society (Hochstetler, 2014; Al Mutawa, 2015). Therefore, the main objective of this paper is to show how the Sultan Qaboos Award for Volunteerism play a vital role in separated the culture of volunteerism as an integral part of the Omani society as a Muslim country, the main objectives of the award as is shown at the Ministry of Social Development portal (2012) are the followings:

1. To consolidate and spread the culture of volunteerism as an integral part of the Omani society's evolving culture, with values, principles, ethics, standards, symbols and practices that encourage initiatives and affirmative actions that benefit the public.

2. To highlight the role of voluntary NGOs and individuals who have contributed to glorious projects by volunteering in them and give them attention and appreciation.

3. To promote the spirit of constructive competition for the community between voluntary and private institutions.

4. To raise interest and attract the young generation to engage in volunteer work and generosity.

5. To activate the aspects of cooperation and social responsibility between voluntary civil institutions, the government and private sector institutions with consequent interdependence, synergy and cooperation.

6. To encourage the initiatives of voluntary and private institutions in increasing their contribution to voluntary projects of distinctive quality that will contribute to the development process.

In recent years, many organizations strive to maximize their efficiencies by investing in their human resources. In many countries around the world, a special day is set aside to recognize and honor the great contributions that philanthropy and people active in our global communities have made to our lives, our local communities and our world. In Oman, many people volunteer for various causes and for different organizations. In addition to this, many in ISSN: 2332-6840 (Online) 2332-6832 (Print) Copyright (C) 2019 by authors, all rights reserved. Authors agree that this article remains permanently open access under the terms of the Creative Commons Attribution License 4.0 International License 
Oman strive to identify, recruit and orient others towards volunteering each year. These people are committed to stimulate volunteer engagement among their friends, colleagues, and their community and as well as their society. This requires a provision of meaningful opportunities for volunteers to be engaged in successful, safe, and meaningful experiences.

There are also other methods to promote philanthropic practices. For example, in education in the United States there has been a steady increase in student philanthropy by applying the "learning by giving" approach, which develop students' awareness of social problems and nonprofit organizations, their beliefs about personal responsibility and self-efficacy, their learning and application of course content, and their intentions to donate money to and volunteer for nonprofit organizations (Olberding, 2012). Olberding (2009) defines education philanthropy as "an experiential learning approach that provides students with the opportunity to study social problems and nonprofit organizations, and then make decisions about investing funds in them" (p. 463). Furthermore, Payton and Moody (2008) define philanthropy as a term that encompasses "voluntary giving...voluntary service....and voluntary association" (p.6).

It has been found that the acquisition of volunteers is important, as is the retention of them too. It is also important to find the right tools to engage volunteers. It is essential to set clear goals for volunteers, which consequently provides ways for volunteers to serve their organization or project's mission. Volunteer work enables people to be more oriented, and concerned about their society. Stein (2011) indicates that volunteerism is an essential component of a non-profit workplace today, especially in light of diminishing financial resources faced by many non-profit organizations. Volunteers have demonstrated their value to non-profit organizations and play an important role in all operations for non-profit organizations. This research answers the following questions:

1. What is the importance of the SQAVW during the four award cycles in promoting philanthropy in social development related to education?

2. What is the effectiveness of the Sultan Qaboos Award for Voluntary Work in promoting philanthropy in social development related to education?

3. Are there any statistically significant differences $(\alpha=0.05)$ between responses on points of view of the importance and the effectiveness Sultan Qaboos Award for Voluntary Work in promoting philanthropy in social development related to education?

\section{Practicing Philanthropy in Societies}

There is an increasing reliance on private philanthropy to meet the basic human needs of societies around the world (Eikenberry, 2005). Today, there are a wide range of philanthropy on offer, also ones that consider private donations of money, property, and time. Philanthropy today is largely directed toward non-profit organizations. In USA alone, philanthropic donations amounts to some $\$ 316$ billion a year; billions more is spent by the philanthropic sector worldwide, and held in trusts and in philanthropic foundations. The funding supports a tremendous variety of organizations and an enormous range of activities. Philanthropy thus raises a host of questions familiar to political theorists such as questions about social and economic inequality, democratic control, influence of the elite, the boundaries between the public and private sector, and the connection between personal moral duties, and the demands of justice.

The political theory of philanthropy also involves the consideration of ethics and politics. It raises the question of what attitudes citizens (more specifically, democratic citizens who regard themselves as free and equal) ought to take toward philanthropic gifts, donors, and the recipients. The acceptance of philanthropic gifts and the terms imposed by donors might look very different depending on the attitudes taken; gifts need not be accepted in the spirit in which they are offered (USAID, 2017).

Philanthropic commitments to support higher education have always been practiced in the American history and Americans have remained steadfast in making significant volunteer. National data from the most recent Voluntary Support of Education (VSE) Survey indicated private support of higher education exceeded \$28 billion in 2010 (Council for Aid to Education [CAE], 2011). Despite this significant contribution, nearly 1,000 of the public community colleges, which make up the largest single segment of post-secondary education in America, benefit least from this generosity. For more than 50 years that the VSE Survey has tracked private support of higher education, it was found that public community colleges consistently underperformed in comparison to all other types of colleges and universities (Love, 2009; Olberding, 2012; Micinski, 2017).

In Russia, Blagov and Petrova-Savchenko (2012) explored philanthropic activities by analyzing evidence from a national awards competition. The study examined how companies, who were officially recognized in Russia as corporate philanthropy leaders, introduced, implemented, and evaluated philanthropic activities. They focused on the connections between these activities and the corporate strategy. The paper sought to investigate the main trends in the development of corporate philanthropy between 2007 to 2010. Their study also assumed that corporate philanthropy was an integral part of corporate social performance. A survey was designed to collect data from participants in the national "Corporate Philanthropy Leaders" awards competition. The competition was conducted by the Russian business newspaper Vedomosti, PwC, and the non-profit grant-making organization "Donors Forum", between 2008 to 2011. The results 
indicate that strengthening connections between corporate philanthropy and corporate strategy, enhances the strategic nature of philanthropy. The different forms of corporate philanthropy examined in this study were segmented into five groups: corporate donations of money; corporate donations in kind (natural forms such as commodities); rendering services; employees' donations; and corporate sponsorship. Monetary donations are still the traditional form of corporate philanthropy, however this is changing across all companies.

In 2010, 96 percent of the companies who responded to the survey used monetary contributions -versus the 100 percent in 2007, 92 percent in 2008, and 94 percent in 2009. At the same time, the companies forms of corporate philanthropy were noticeably diverse. The proportion of companies using donations in kind (commodities) grew from 42 percent in 2007 , to 47 percent in 2008 , to 43 percent in 2009, and to 59 percent in 2010 . Rendering services as a form of charity also increased. It increased from 42 percent in 2007 to 43 percent in 2008, 40 percent in 2009, and 45 percent in 2010. Employee donations also increased from 21 percent in 2007 to 45 percent in 2008 , to 55 percent in 2009, and to 57 percent in 2010.

\section{Volunteerism and Philanthropy in Higher Education}

Roger (2013) draws our attention to the Association of Fundraising Professionals (AFP) which advances philanthropy by enabling people and organizations to practice ethical and effective fundraising. AFP believes philanthropy is so powerful and inspiring because it is voluntary - that through the goodness of our hearts, our need to connect, and our desire to see a better world, we come together to improve the quality of life for all people. He showed that through the generosity of our communities, millions of dollars and millions of volunteer hours are given every year to worthy organizations, non-profit entities and charities in the region. Hundreds of programs and services that help people who are homeless, clothe people in need, support student bursaries, and redevelop our local hospitals, are made possible every day because of people's commitment to their respective causes. For non-profit entities, volunteers are an essential part of the fabric of our community. They are partners that help us fundraise and generate revenue and also work as board members to govern our organizations.

Volunteerism and philanthropy has played a pivotal role in the history of higher education in America long before it became a nation. The generosity of individuals made the founding of the first college, Harvard University, a reality in 1636. A case study was conducted by Hammond (2012) at a public community college in the USA to explore a selection of stakeholders' perceptions and to gain an understanding as to why they made significant commitments of volunteerism and philanthropy to a capital campaign at one public community college. The study also tried to identify specific factors that influenced their decisions. There seems to be a lack of research and data available that examines this topic from a volunteer or donor perspective, therefore his study provides a unique insight into these phenomena. Given that community colleges are experiencing significant decreases in public revenue, and are seeking to offset the decline with private support, his study is critical to guide the fundraising efforts of college leaders. Additionally, his study offers an understanding into philanthropic support of a program that served immigrant students, and provided insight into alternative resources that community colleges used to sustain their pivotal mission of providing affordable and accessible education to diverse populations.

Qualitative interviews with 12 stakeholders were conducted which was supplemented by a review of documents and a reflection of their personal volunteer and philanthropic narratives, and their experience with the campaign. This provided an in-depth understanding of their shared phenomena. Four major themes were tested: Heritage Philanthropic Narratives, Association, Harmonics, and Loyalty as well as the critical interrelationship among them. It was found that an interconnected array of aligned values and process concepts had developed, illustrating the deep-seated relationship of the stakeholders to the foundation and the college. Although the Association Theme was central to the relationship among the themes, it appears no one particular theme stood alone. Instead, the themes had a cohesive arrangement of complex behavior - an interrelated, self-nurturing, and recursive social eco-system. It is likely that the study has found a system consisting of four themes which also represents a theory of volunteerism and philanthropy which is more specific to community colleges.

Saunders-Hastings (2014) explains how philanthropy is still considered to be an unproblematic way for individuals (especially the rich) to help recipients and society by "giving their money away." He also shows how philanthropy also provides donors with influence and authority, and these powers can be subject to criticism on democratic and egalitarian grounds. He tries to frame philanthropy as a way for private money to shape public options and choices open to individuals. He argues that if people focus narrowly on the intentions of the giver, or on the immediate distributive outcomes of philanthropic gifts, then the political importance of philanthropy is overlooked.

\section{Promoting Philanthropy among Students and Organizations}

In his review of literature, which promotes philanthropic activities in education, Olberding (2012) identifies a type of student philanthropy which is used as a teaching strategy to engage students actively in their curriculum. This type of philanthropy increases awareness of social needs and non-profit organizations available. His study examines the 
long-term effects of student philanthropy by surveying alumni years after their experience with this type of teaching strategy. A majority of the respondents indicated that student philanthropy had a positive effect on their awareness, learning, beliefs, and intentions. Furthermore, $86 \%$ of the student philanthropy alumni had recently made charitable contributions, $71 \%$ reported being involved in volunteering, and $15 \%$ served on non-profit boards - all of which are much higher than the national averages for these percentages.

Another study conducted by Geiser, Okun, \& Grano (2014) made a comparison between Italian and American college students in order to identify the factors that motivated people to volunteer. The results suggested that external incentives may undermine an individual's intrinsic motivation to volunteer. Gender differences in the frequency of volunteering were not found, although it was found that highly motivated males were more prevalent. In terms of differences identified between the two countries, overall, Italian students reported volunteering less frequently, but were more prevalent in the highly motivated category used in the study. Another study conducted by Ryder (2005) investigated college student volunteerism, and the role that time spent participating in volunteer activities added towards a predictive model of psychological-wellbeing. Results indicated that all of the psychological well-being measures positively and significantly correlated with each other. Significant correlations between demographic variables and some of the psychological well-being measures were also found. On the topic of volunteering services, a significant correlation has been found between time spent participating in philanthropic volunteer activities and a student's confidence and optimism in their academics. Results also reflect that time spent participating in volunteering services is not found to be significantly predictive of scores on psychological wellbeing.

In the discussion relating to organizations, White (2016) indicates that the volunteer workforce is a critical asset within many different types of organizations. The purpose of his study explores the unique dynamics associated with managing a volunteer workforce, and identifies best practices and effective strategies for enhancing or improving philanthropic effectiveness. He posited that volunteers have different motivations to a paid workforce. Examining the motivations that underpin volunteers is therefore essential to determine how to positively influence the job performance of a volunteer workforce. In order to build a strategy for volunteerism, organizations running different voluntary activities should engage in different strategies. Essential strategies for volunteer management include acquiring, developing, and maintaining a volunteer workforce.

Hochstetler's (2014) study used the valuable Volunteer Functions Inventory (VFI) model, which has been in use for over ten years. His study received significant attention from researchers as it was a qualitative study aimed to identify missing functions that should be part of the VFI inventory. Hochstetler's analysis supports the use of six functions included in the VFI. He also supports additional concepts such as civic responsibility, and debt or obligation as philanthropic functions that can provide motivation for volunteerism. Using Hochstetler's results, we were of the consensus that civic responsibility and debt or obligation are functions that should be included in the VFI, and were considered during this study.

In order to develop philanthropic volunteering as a theory, Al Mutawa (2015) uses the social exchange theory model, human resource management theory, volunteer functional inventory model and the volunteer satisfaction index to theoretically underpin and validate his emergent theory. His work contributes to the knowledge on the application of management theory, which is widely used in profit making organizations, to non-profit and volunteer dependent sectors. The results from his research indicated that two volunteer management practices correlate, namely volunteer training and support, and volunteer performance management and recognition. These volunteer management practices were found to indirectly influence volunteer retention. The research findings contribute towards understanding social exchange and Human Resources Management (HRM) theories concerning the relationship between volunteer management practices and volunteer retention.

\section{Promoting Philanthropy among Leaders}

In order to develop a strategy to retain long-term volunteer leaders, Nihart (2012) conducted a qualitative study to develop a theory grounded in perceptions and behaviors of participants to explain the ability of long-term volunteer leaders to remain in positions of continuous leadership. Results from the study indicate a number of factors that affect long-term volunteer leaders in positions of continuous leadership. Being connected to like-minded people who share similar passions was a major factor. Retaining these leaders is essential to sustaining the benefits of social change such as the ones volunteer organizations provide to communities Trauntvein (2011) indicates that managers who care about the sociocultural environment of their organizations should strive to provide situations where volunteers can make a notable difference and in cases where this is not possible, they should encourage and acknowledge the efforts of volunteers. Since volunteer leaders develop a strong sense of identity with the organizations that they lead, they tend to view the organization's successes and failures as their own. Consequently, this can be very positive for the retention of managers involved in volunteer-driven organizations.

In order to reduce volunteer turnover, Love (2009) studied the annual value of philanthropic volunteer labor in the United States. It has been estimated to be worth over a 
quarter of a trillion dollars. Correlation and regression analysis were used to test the relationship between motivations to volunteer, factors representing festival context and volunteer retention. The analysis extended support of the findings from a prior study, suggesting that both motivation factors and volunteer experiences are related to volunteer retention. This study produced a robust model to understand the influences on the decision to continue to volunteer for the same organization.

Vaske (2008) examined the relationship between a person's motivation to volunteer and their preferred organizational culture. His study concluded that people with similar reasons for volunteering will share similar organizational cultural preferences of the volunteer organization. Identifying the relationship between the motivation to volunteer, and an organizational cultural preference is important, as it assists volunteer organizations in their management of and marketing to volunteers. The results of the study show that there are statistically significant positive relationships between a) a Understanding motivation and a preference for an adhocracy culture, $b$ ) a values motivation and a preference for a Market/Rational Goal culture, c) a Social motivation and a preference for a Clan culture, and d) a Protective motivation and a preference for a Hierarchy culture. Furthermore, in the exploration of an individual's motivation for volunteering, Stein (2011) suggests strategies to assist with the retention of volunteers, since volunteers play a critical role in the success of non-profit entities, and past research on volunteerism illustrates the value inherent in individuals towards providing high-quality programs. The results of the study demonstrate that respondents reasons for volunteering were based upon a 'feel good factor'.

\section{Philanthropy from an Islamic Point of View}

Philanthropy and charity are considered to be a backbone of the Islamic commitment towards personal and social responsibility. Indeed, many Muslims regard charity as a form of worship. According to traditional conceptions of Islam, charity is one of the five pillars of the faith (along with prayer, belief in God and the Prophet Muhammad, fasting in Ramadan, and pilgrimage to Mecca). In Muslim conceptions of faith and community, humans are linked to each other through their obligations to God. A charitable act is therefore not merely an act of faith, nor an act for the community. It is the building of a community through faith, and the building of faith through deepening ties within a community (USAID, 2006). The idea of philanthropy is further elaborated in the Islamic concept of joint liability (takaful), or the responsibility of each Muslim for every other Muslim. In this structure, charity is not so much an act of piety as it is an obligation. It is perhaps the importance of charity that contributes to Islam's emphasis on the idea of social justice, both as a societal ideal and as a responsibility of the government. There is the expectation that everyone should be provided with equal opportunities, Islam expects leaders to feed the hungry, heal the sick, and house the orphans and widows, and it expects all Muslims - be they rich or poor - to contribute to such efforts.

Each Muslim individual carries out and understands his or her own acts of philanthropy in a way that varies from individual to individual, and may vary in time with the same individual. Rather than propose a formula for philanthropic action, this study aims to make readers aware of opportunities and possibilities which they were unaware of prior to this study. Taking the opportunities and putting them into practice will depend on the resources that are available, institutional commitment, local partners available, and most importantly, a desire to see that philanthropic action come to fruition. As the practice of philanthropy has existed for a long time in the history of Muslim societies, and with it playing such a central role in the Muslim faith, it is not surprising that there is an elaborate set of rules and many institutions that govern philanthropic work in Muslim communities. Despite the common presumption within Muslim communities that Muslim practices have been consistent from time immemorial, the rules (like many aspects of Islam) have differed greatly over time. To put it simply, philanthropy is considered as acts done for the welfare of mankind. Every religion has philanthropic components to it, and Islam is no exception. In fact, Islamic rulings make acts of charity obligatory.

\section{Formal versus Informal Philanthropic Practices in Muslim Societies}

There are two types of philanthropic practices in Muslim societies. There is a mistaken impression that Muslims systematically favor formal institutions over informal ones. The reality is not the case. Individual philanthropic acts are far more likely to be directly exchanged between a donor and recipient rather than funneled through a formal institution. This goes some way towards explaining the prevalence of beggars in many Muslim societies. At the same time, there is a widespread distrust of formal Western-style foundations, which many in Muslim-majority societies reportedly see as businesses rather than philanthropic institutions. Consequently, community trust of such institutions remains rather low. One of the advantages religious figures have in running philanthropic enterprises is that they are presumed to be trustworthy, thereby fulfilling a Muslim's religious obligation to give, as well as giving the donor confidence that their money will be channeled to an acceptable cause. Some Muslims argue that their responsibility for where the money goes should end with their fulfillment of the obligation to give, and intermediaries should be pursued for all activities beyond that (USAID, 2006). 


\section{Types of Obligation and Philanthropy in Islam}

Islam as a religion prescribes charitable giving in many ways and styles, some of them are obligatory, while others are not. Islam, through the Qur'an and Sunnah, places great emphasis on Muslims to practice charitable giving, its expresses concern for the well-being of others, and enables communal harmony between the wealthy and the poor. Recognizing this can provide fundraising professionals (and the charitable-sector) with a understanding of the philanthropic inspirations and values of Canadian Muslims. Shams Vellani (2004) clarifies that the Quran explains the practice of philanthropy in Islam and that the continuing commitment, through health and educational support, of sharing of knowledge and expertise towards helping the vulnerable, enhances a donor's capacity for self-improvement.Unfortunately, no reliable figures exist to measure the magnitude of philanthropic giving in Muslim communities, but it is estimated to total between $\$ 250$ billion and \$1 trillion annually. This estimate takes into account approximations per capita in some countries, per capita income in Muslim-majority countries, religious injunctions to donate at least 10 percent of one's income to charity, and other factors.

There are two types of philanthropy in Islam: obligatory and voluntary. Obligatory philanthropy consists of zakat and zakat-ul-fitr or fitrana, whereas voluntary philanthropy includes the sadaqah and waqf institutions. The types of philanthropy are shown in Figure 1. The following explains them individually:

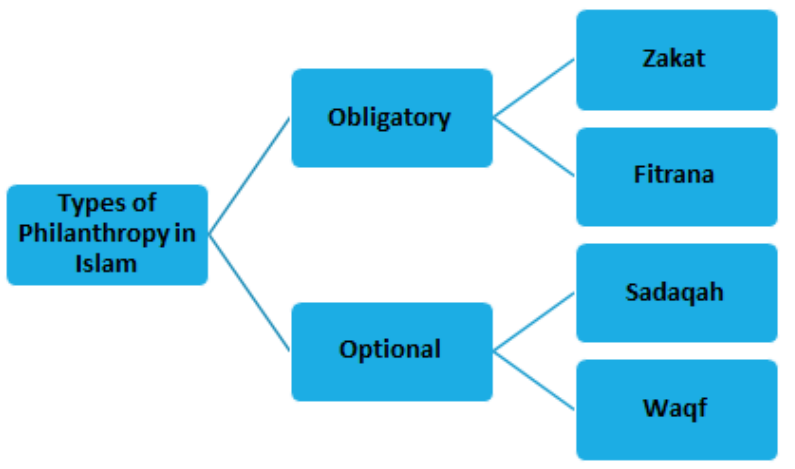

Figure 1. Types of philanthropy in Islam

1-Zakat. Also known as Zakat-ul-mal, literally means "to be clear, to grow, to increase." Zakat is a pre-determined share of wealth, prescribed to Muslims who have resources remaining after meeting the basic needs of their families. It is to be distributed amongst various categories of those entitled to receive it. Muslims who maintain the designated minimum amount of wealth for the full cycle of a lunar year must, as a matter of worship, satisfy their duty of giving zakat. The amount payable is determined based on the amount of cash and type of assets an individual has. The Qur'an does not specify a prescribed percentage, but the customary practice is to pay $2.5 \%$ on capital assets and $20 \%$ on other assets such as agricultural goods, precious metals, minerals, and livestock.

2-Fitrana. Also known as Zakat-ul-fitr or Fitrah, is paid before the end of the month of Ramadan. The primary goal of Fitrana is to provide those in need with the ability to celebrate Eid-ul-Fitr, the festival of breaking the fast, along with the rest of the Muslims. Every mature and financially able Muslim is required to pay the Fitrana for themselves and on behalf of their dependents. In the context of Fitrana, a dependent refers to anyone who is in a person's care. This could mean their children, parents, siblings, or any individual for whom one is responsible. The prescribed amount payable for Fitrana is the same for all Muslims, regardless of their income bracket or wealth. However, if an individual is unable to meet their own expenses as well as those of their family, for a period of one lunar year (and has no one who can meet these expenses for them), they are exempt from Fitrana.

The Qur'an (in Chapter 9, Verse 60) outlines eight types of individuals or causes that can be beneficiaries of Zakat and Fitrana funds:

1. Those living without a livelihood, i.e. the destitute

2. Those who cannot meet their basic needs, i.e. the ones in need

3. Collectors of Zakat, i.e. clergy or administrators

4. Those sympathetic to or expected to convert to Islam, i.e. recent converts to Islam and potential allies in the cause of Islam

5. To free individuals from slavery or servitude

6. Those who have incurred overwhelming debts while attempting to satisfy their basic needs

7. In the path of God, i.e. the advancement of religion

8. Wayfarers, i.e. stranded travelers and/or travelers who are traveling with few resources

Furthermore, there are also different types of voluntary philanthropy in Islam which reflect acts of giving. The following are the different types:

1-Sadaqah. This can be described as any act of giving and kindness which an individual chooses to do to help another. In Arabic, the word 'Sadaqah' means "voluntary charity". Sadaqah often goes beyond financial contributions to include any act of giving out of compassion or generosity that is done to benefit others

2-Waqf. This can be described as the transfer of property, such as a building, land, or cash, by Muslims for religious or charitable purposes, with no intention to reclaim the assets. Similar to bequests or estate gifts, the purpose of Waqf is to provide an everlasting benefit to the beneficiaries, and the donated assets may be held by a charitable trust. Every waqf contract is required to have a founder, a trustee, a judge and beneficiaries. Under both a waqf and a trust, the endowment or property is reserved only for the use and benefit of the purpose (be it general or specific) identified in the contract (National Zakat Foundation of Canada, 2017). 


\section{Philanthropy in Oman}

In Oman, philanthropy is practiced in many ways. Similar to most Moslem countries, philanthropy and altruism, to the less privileged in society in particular, guides social interactions at all times, but especially during the religious period of Ramadan. Indeed, it has been found that Islam has been positively correlated with the philosophy and practice of Corporate Social Responsibility CSR (Minnee et al., 2013). Whilst CSR philosophy and practice in emerging economies tends to be primarily characterized as philanthropy and altruism (Koladkiewicz, 2009; Szczepanski et al., 2009; Imbun, 2007; Amaeshi et al., 2006; Eweje, 2006), there is scope to further understand this concept within cultural, religious and societal frames.
It is estimated that the total value of donations made in Oman since 2009 reached 2,491,526,99 OMR with the total number of contributors totaling 94,162 and the total number of charities totaling 25 . In 2017 , the total value of donations raised between January 1st to 4th July 2017 totaled nearly 400,747.72 OMR with the total number of contributors totaling 13,045. Appendix 1 demonstrates the total amount raised per charity (from 2009 - 2017) in Oman (Ministry of Social Development, 2017). The below diagram demonstrates the total amount raised per charity in Oman.

The estimated number of donors in Oman is shown in Diagram 2.

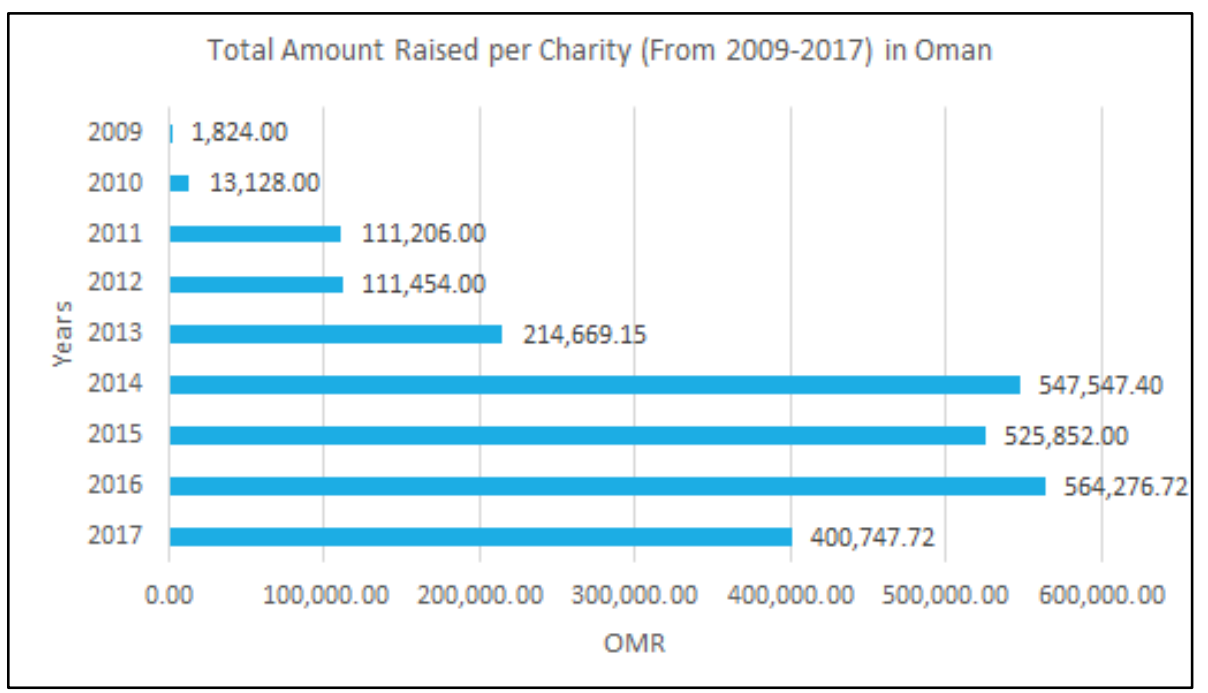

Diagram 1. Total Amount Raised per Charity (From 2009-2017) in Oman

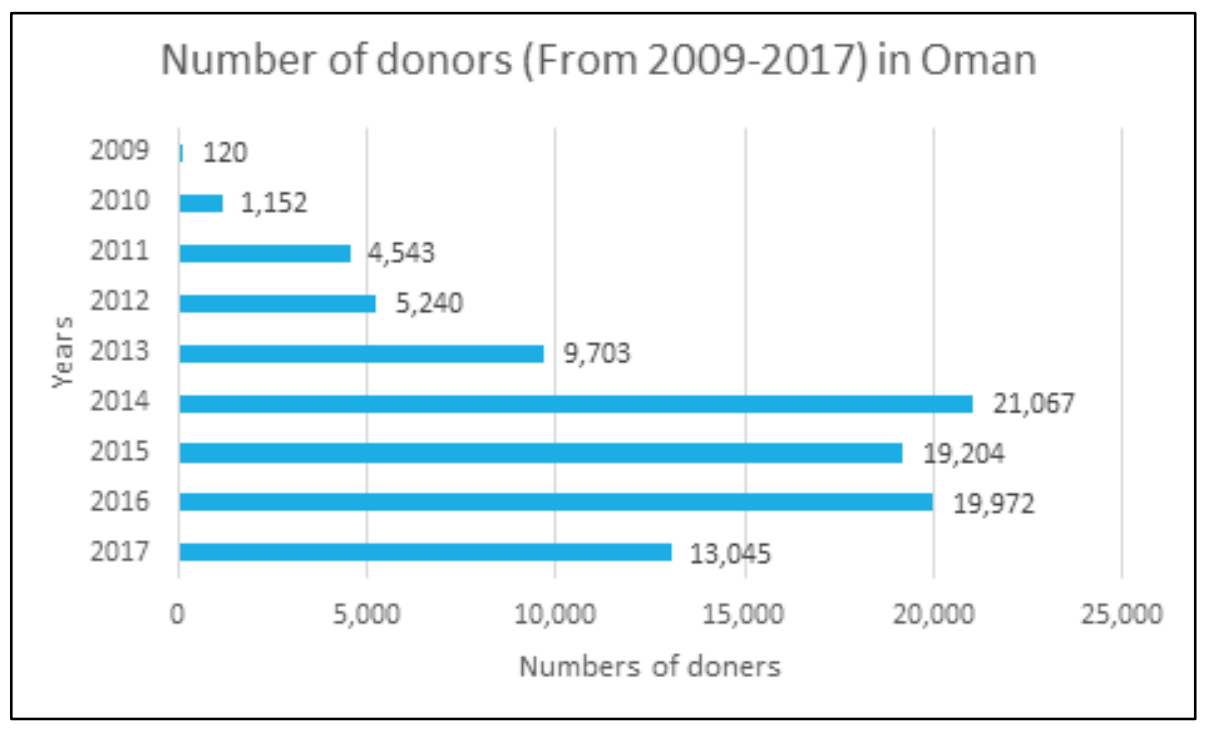

Diagram 2. Number of donors (between 2009-2017) in Oman 


\section{Brief Glance at the Sultan Qaboos Award for Volunteerism}

The Sultan Qaboos Award for Volunteerism (Ministry of Social Development, 2012) is one of the first awards to promote volunteerism in the Sultanate of Oman. It is also an important event for the promotion and encouragement of volunteerism in all forms, especially at a stage where support and cooperation with voluntary work is needed. The Award's vision is to activate voluntary work, deepen its reach to its target audience and extend its reach to include new categories and innovative activities in the Omani society and to build a national heritage in the field of voluntary work. Furthermore, the contribution of the award is to the development of a high-level dimension that can lead to sustainable and renewed voluntary work. However, the mission of the award is built around encouraging and activating the role of community institutions (NGOs) and individuals in the field of voluntary work. Companies and individuals who support volunteering based on a social responsibility complement the role played by government units in order to achieve a distinguished role in social work activities in various fields to meet the needs of society.

The Sultan Qaboos Award for Volunteerism is the first award of its kind in the Sultanate of Oman, which supports and encourages volunteer efforts in all its aspects without exception. The Award is dedicated to all segments of society and various institutions. It is also a unique opportunity to honor all those who engage in voluntary efforts, ideas and projects without waiting to be rewarded. Finally, it expresses appreciation and encouragement to all those who support and establish voluntary efforts in various fields. It draws attention to the fact that those who establish and support voluntary institutions in the Sultanate of Oman are role models. Upon the review of the above literature, the aim of this study is to assess the voluntary sector in Oman. This sector has witnessed a remarkable growth over the last few years, which significantly impacts the activation of social mobility and contributes positively to development plans for Oman. In order to achieve the study aims, identifying the current practices of the voluntary sectors in Oman was required, and from there, the researcher sought to analyze the challenges faced by the voluntary sector in Oman using the SWOT for looking at the at effectiveness and importance of the award and develop indicators from the results of the analysis. At the end of this research, the researcher expects to achieve the following outcomes:
1. Showing the effectiveness of the Sultan Qaboos Award for Volunteerism in Omani society.

2. Highlighting the importance role of the Sultan Qaboos Award for Volunteerism in Oman society.

3. Identifying the best practice of volunteer project practices and develops criteria that can be utilized in order to increase the added value of SQAVW in Oman.

\section{Conceptual Framework of the Study}

The main concept of a volunteer is defined by White (2016, p 2) to be "an individual who offers his or her time and talents for the benefit of an individual, group, or organization without the expectation of financial compensation". Looking at volunteering values, it is indicated that volunteers provide much more than manual labor, they perform many tasks and hold positions of leadership at all levels of organizations.

The Merriam Webster dictionary defines philanthropy as goodwill to fellow members of the human race and an active effort to promote human welfare. It is also an act or gift done or made for humanitarian purposes. The concept of philanthropy includes "love of humanity" in the sense of caring for, nourishing, developing, and enhancing "what it is to be human" for both the benefactors (by identifying and exercising their values in giving and volunteering) and the beneficiaries.

In the Sultanate of Oman, volunteer work falls under the responsibility of the Ministry of Social Development. In Oman, the total number of non-governmental organizations is 123 , and more than half number of them are branches of the Omani Women's Association. The Rural Women's Development Centers are also fall under the supervision of The Omani Women's Association. The Omani Women's Association (OWA) is a social and cultural organization aimed at advancing Omani women on all social and cultural fronts. In coordination with multiple government organizations, the OWA strives to empower Omani women to enter and engage in voluntary social work and to advocate cultural, social, and health awareness among Omani women. The goal of the OWA is to improve the economic and social standing of Omani women and to train women to locate and obtain sources of income as shown in figure 2 (Ministry of Social Development, 2016).

The conceptual framework of the study was drown from the Islamic thoughts and the SQAVW objectives as shown in figure 3. 


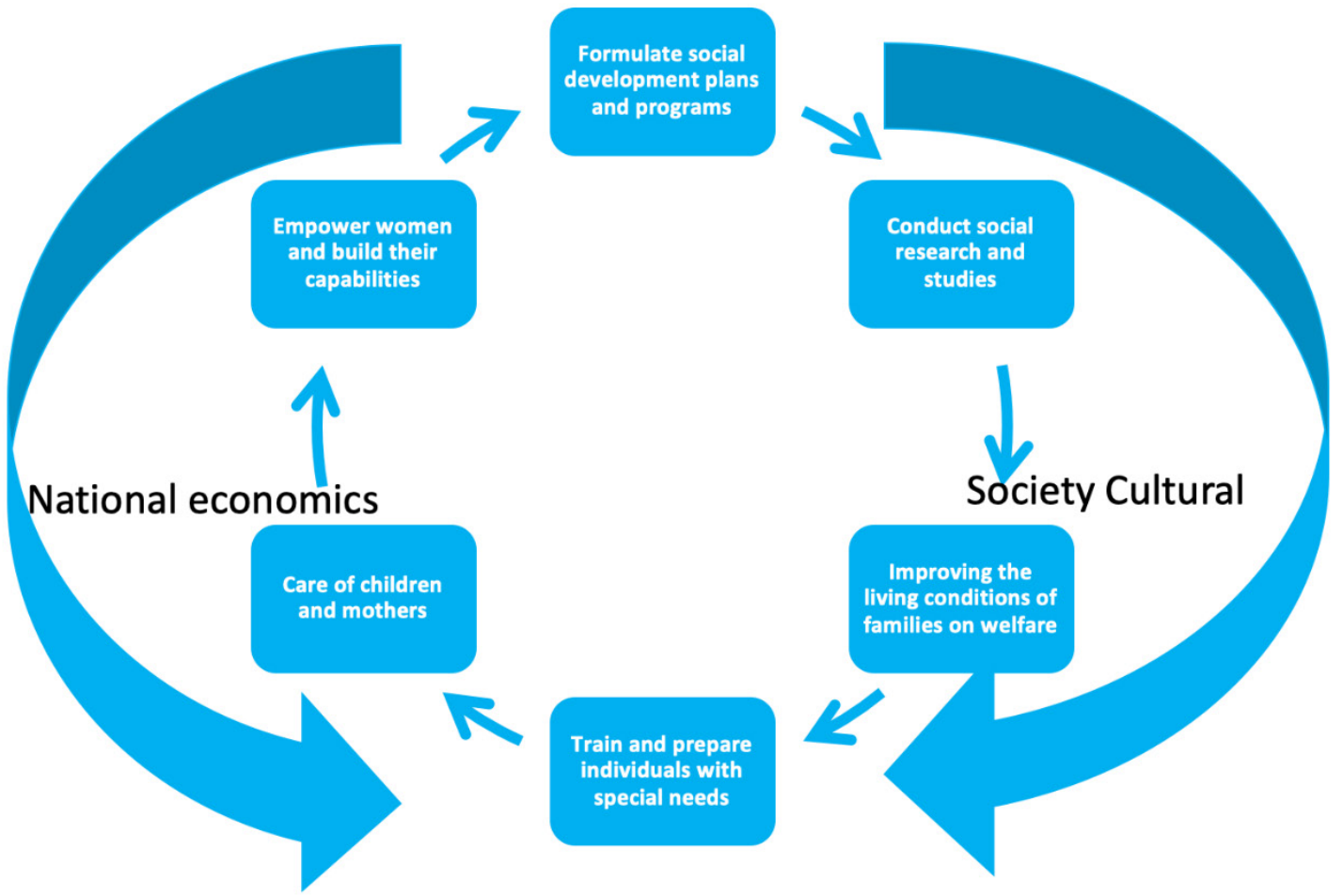

Figure 2. The OWA Conceptual Framework
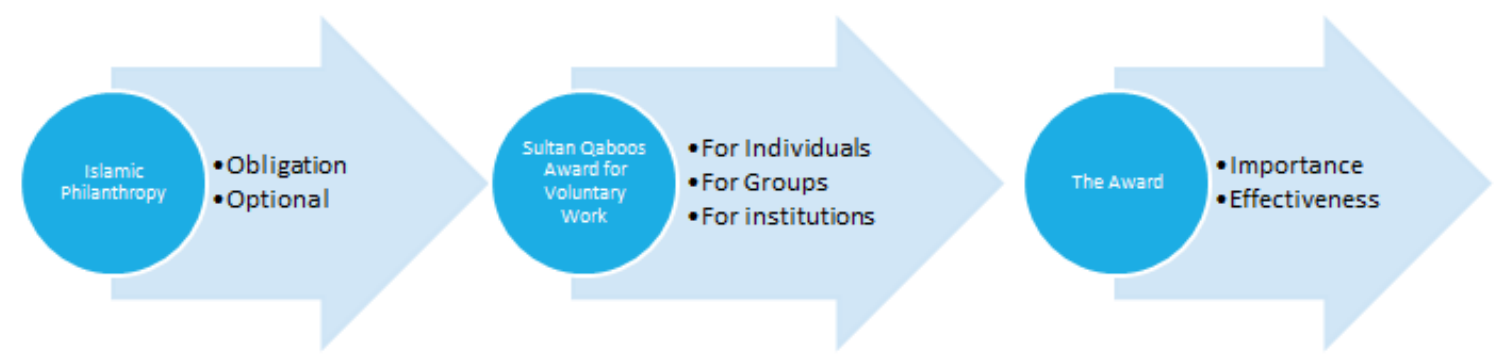

Figure 3. The Study Conceptual Framework 


\section{Method}

The purpose of this study was to examine the promotion of philanthropic activities in education through national incentives by highlighting the case of the Sultan Qaboos Award for Voluntary Work. It focused on the participants who were winners of the Sultan Qaboos Award between 2011 and 2015 and whether their voluntary projects are still active to promote philanthropy in social development related to education. The material for the study was gathered through quantitative and qualitative interviews conducted with 17 award winners, who were individuals, groups and societies. This study also attempted to investigate the role of the Sultan Qaboos Award for Voluntary Work in promoting philanthropy in various social development aspects.

This research is, by nature, a quantitative study and the main instrument of this study is a questionnaire developed by generating a list of factors derived from various literature. (Ryder, 2005; Vaske, 2008; Trauntvein, 2011). These factors are related to the importance and effectiveness of the awards for philanthropic practice. The instrument of the study was validated by a group of specialists in the area of education, volunteer work, educational administration, and education psychology in the college of education at Sultan Qaboos University (SQU).

A Liker-type with a scale ranging from $1=$ very low to $5=$ very high was used to correct respondents points of views in promoting philanthropic activities in education through national incentives. A theoretical mean of 3.00 (mid-point of the scale) was determined as a criterion to judge the means. To determine the reliability of the instrument, the Chronbach-Alpha was estimated as shown in Table 1.

Table 1 demonstrates the result of the instrument reliability using Chronbach-Alpha which is found to be $(0.0 .865)$ on the total items, $(0.884)$ for the importance of awards, (0.700) for effectiveness of the awards. In terms of sample size, a sample of 17-responses was gathered from winners of the Sultan Qaboos Award between 2011 and 2013. Detail of the study sample is shown in Table 2.

The study sample in Table 2 represents 17 participants from five provinces in Oman. Nine of them have experience in volunteer work of four years and less, while eight of them have five years and more.

Table 1. The reliability result of the questionnaire

\begin{tabular}{ccc}
\hline Domains & Items & Cronbach's Alpha \\
\hline Importance of Awards & $1-17$ & 0.884 \\
\hline Effectiveness of award & $18-29$ & 0.700 \\
\hline Total & $1-29$ & 0.865 \\
\hline
\end{tabular}

Table 2. The demographic description of the study sample

\begin{tabular}{cccc}
\hline Variables & Type & Frequency & $\%$ \\
\hline \multirow{4}{*}{ Provinces } & Muscat & 9 & 52.9 \\
\cline { 2 - 4 } & AL Dhahirah & 1 & 5.9 \\
\cline { 2 - 4 } & AL Dakhiliyah & 5 & 29.4 \\
\cline { 2 - 4 } & AL Sharqiyah & 1 & 5.9 \\
\cline { 2 - 4 } & Dhofar & 1 & 5.9 \\
\hline \multirow{3}{*}{ Award year } & 2011 & 4 & 23.5 \\
\cline { 2 - 4 } & 2012 & 6 & 35.3 \\
\cline { 2 - 4 } Experience in volunteer \\
work & 2013 & 7 & 41.2 \\
\cline { 2 - 4 } & 5 years and more & 8 & 52.9 \\
\hline Total & & 17 & $100 \%$ \\
\hline
\end{tabular}

\section{Study Result}

In order to answer question number one, data of the SQAVW was collected from the Director General of Social Care (2017) and analyzed as shown in Table 3.

The result in Table 3 shows that during the fourth cycle of the SQAVW there were 27 winners, 15 of them were groups and societies, while 12 of them were individuals. The total amount of the all four cycles reached a total of OMR 450,000.00. The data in Table 3 shows that the awards are represented by a variety of social services such as philanthropic, social, handicapped, health, education, technology information and the environment. The results also show that the most frequent award field is philanthropic and social projects.

Table 3. Distribution of the total amount of SQAVW in OMR from 2011-2015

\begin{tabular}{|c|c|c|c|c|c|}
\hline \multirow[t]{2}{*}{ Award cycle } & \multirow[t]{2}{*}{ Year } & \multirow[t]{2}{*}{ Award fields } & \multicolumn{2}{|c|}{ Number of the Winners } & \multirow[t]{2}{*}{ Total OMR } \\
\hline & & & Groups/ societies & Individuals & \\
\hline $1^{\text {st }}$ cycle & 2011 & $\begin{array}{l}\text { Philanthropic, social, handicapped, } \\
\text { health }\end{array}$ & 4 & 3 & $120,000.00$ \\
\hline $2^{\text {nd }}$ cycle & 2012 & $\begin{array}{l}\text { Culture, social, education, health, } \\
\text { environment, information technology }\end{array}$ & 4 & 3 & $100,000.00$ \\
\hline $3^{\text {rd }}$ cycle & 2013 & $\begin{array}{l}\text { Information technology, health, } \\
\text { social, philanthropic }\end{array}$ & 3 & 4 & $108,000.00$ \\
\hline \multirow[t]{2}{*}{$4^{\text {th }}$ cycle } & 2015 & $\begin{array}{l}\text { Children and youths, social, } \\
\text { philanthropy, handicapped }\end{array}$ & 4 & 2 & $122,000.00$ \\
\hline & & Total & 15 & 12 & $* 450,000.00$ \\
\hline
\end{tabular}

*One OMR equals to $2.60 \$$ 
Question number one aims to analyze the effectiveness of the Sultan Qaboos Award for Voluntary Work in promoting philanthropy in social development related to education. To meet the objectives of this question, data was analyzed using a SPSS package which computed the means and standard deviation for each domain and the total that reflected the respondents point of views. The result of this study identified the importance and effectiveness of the Sultan Qaboos Award for Voluntary Work (SQAVW) in promoting philanthropy in social development related to education. This is shown in Table 4.

Table 4. Means and standard deviation of responses for each domain and the total

\begin{tabular}{ccc}
\hline Domains & Mean & S.D \\
\hline Importance of the award & 4.28 & 0.450 \\
\hline Effectiveness of the award & 4.18 & 0.457 \\
\hline Total & 4.24 & 0.385 \\
\hline
\end{tabular}

The result in Table 4 shows that the responses demonstrate the value of the SQAVW as it promotes different types of philanthropic practices and social development in Oman. The highest mean of the distribution is for the importance of the award (4.28), this is followed by the effectiveness of the award with a mean of
(4.18). The total of the means are also estimated to be very high with a value of (4024).

\section{The First Domain: Importance of the Award}

The mean and standard deviation is estimated for each item in each domain as shown in Table 5 .

The result in Table 5 shows that there are 17 statements which represent the importance of the SQAVW. All mean values of responses' point of view are very high (4.76) for the statement "Promoting the culture of volunteerism in Omani society" and also high (4.00) for the statement "Activating the participation of civil society institutions in sustainable development planning". The result in Table 5 indicates that all the responses agree that the award attracts new individuals to volunteer work with the mean value of 4.47. The responses show that the SQAVW has very high impact on increasing the sense of people loyalty and belonging to the homeland with a mean of 4.41 , and it promotes positive competition among volunteers with mean value of 4.41. Furthermore, it promotes the principles of positive voluntary work with mean value of 4.29. The lowest mean value in Table 4 is for the statement "activating the participation of civil society institutions in sustainable development planning" with a mean of 4.00 .

Table 5. Means and standard deviations of the responses for the importance of the award domain

\begin{tabular}{ccccc}
\hline Rank & $\#$ & Statements & Means & SD \\
\hline 1 & 2 & Promoting the culture of volunteerism in the Omani society & 4.76 & 0.437 \\
\hline 2 & 1 & Encouraging young people to volunteer & 4.70 & 0.469 \\
\hline 3 & 9 & Attracting new individuals to voluntary work & 4.47 & 0.799 \\
\hline 4 & 4 & Increasing a sense of loyalty and belonging to the homeland & 4.41 & 0.870 \\
\hline 5 & 6 & Promoting positive competition among volunteers & 4.41 & 0.507 \\
\hline 6 & 8 & Promoting the principles of positive voluntary work & 4.29 & 0.587 \\
\hline 7 & 12 & Achieving humanitarian goals through caring for others & 4.29 & 0.771 \\
\hline 8 & 15 & Promoting constructive competition between voluntary institutions in the community & 4.29 & 0.771 \\
\hline 9 & 3 & Activating cooperation between voluntary institutions and civil society associations & 4.23 & 0.970 \\
\hline 10 & 10 & Developing positive community service values in young people & 4.23 & 0.831 \\
\hline 11 & 16 & Encouraging voluntary initiatives to contribute in the development process & 4.23 & 0.970 \\
\hline 12 & 5 & Developing a social sense and adaptation with others & 4.17 & 0.635 \\
\hline 13 & 14 & Developing social responsibility values in young people & 4.11 & 0.696 \\
\hline 14 & 11 & Developing a sense of faith in the individuals through philanthropic actions & 4.05 & 0.899 \\
\hline 15 & 13 & Creating a generation of young people who are able to deal with crisis and solve problems & 4.05 & 0.658 \\
\hline 16 & 17 & Inculcating noble values related to philanthropy in local individuals in society & 4.05 & 0.747 \\
\hline 17 & 7 & Activating the participation of civil society institutions in sustainable development planning & 4.00 & 1.000 \\
\hline
\end{tabular}




\section{The Second Domain: Effectiveness of the Award}

The mean and standard deviation for effectiveness of the award domain is shown in Table 6.

The result in Table 6 shows that there are 12 items that represent the effectiveness of the award. The responses indicate that there are many criteria that the awarded projects should meet. The most effective criteria is related to its social benefits with a mean of (4.88) out of (5.00), followed by the criteria for projects' to have clear executive procedures (4.58), then the criteria of the project to have philanthropic volunteer work characteristics (4.52). Furthermore, the results show that the benefit of the project and its reflection on a large segment of the society (4.23), and the project consistency with the national sustainable development plan (4.17) is considered to be very important criteria. Moreover, there are other criteria which is related to project sponsors, and authority which should be more organized in order to protect its continuity. In order to test the significant differentiation between the respondents point of view toward each study domain and the total result, a T-test was estimated as shown in Table 7.

The T-test result in Table 7 shows that there aren't significant differences between the respondents point of view mean values which are $(\alpha=0.05)$ in each study domain and the total years of experience in the voluntary work variable. This result reflects a similarity among the responses towards the importance and the effectiveness of the award domains.

Table 6. Means and standard deviations of the responses for the effectiveness of the award domain

\begin{tabular}{crrrrr}
\hline Rank & $\#$ & Statement & Means & SD \\
\hline 1 & 18. & The project should have a social benefit impact & 4.88 & 0.332 \\
\hline 2 & 26. & The project should have clear executive procedures & 4.58 & 0.618 \\
\hline 3 & 22. & The project should be characterized as philanthropic volunteer work & 4.52 & 0.799 \\
\hline 4 & 24. & The project should be beneficial for large segments of society & 4.23 & 0.831 \\
\hline 5 & 27. & There should be a guarantee for the continuity of the project & 4.23 & 0.903 \\
\hline 6 & 20. & The cost of the project should be suitable for its executive resources & 4.17 & 0.882 \\
\hline 7 & 23. & The project should be consistent with the country's sustainable development plans & 4.17 & 1.074 \\
\hline 8 & 21. & The idea of the project should be innovative & 4.11 & 1.053 \\
\hline 9 & 28. & The project should have qualified and excellent trained human resources & 4.11 & 0.927 \\
\hline 10 & 29. & The project should have sponsors (government, private) & 3.82 & 1.131 \\
\hline 11 & 25. & The project should work under an authorized organization to maintain its continuity & 3.70 & 1.311 \\
\hline 12 & 19. & The project should produce an added value to the national economy & 3.58 & 1.121 \\
\hline
\end{tabular}

Table 7. T-test results for years of experience in volunteer work which reflect the responses for each domain and the total of the figures

\begin{tabular}{|c|c|c|c|c|c|c|}
\hline Domains & Experience variable & Df & Mean & Std. Deviation & t-value & Level of significance \\
\hline \multirow{2}{*}{ Importance of the awards } & 1-4 years & 16 & 4.4444 & .49400 & 1.640 & 0.122 \\
\hline & 5 years and more & & 4.1029 & .33828 & & \\
\hline \multirow{2}{*}{ Effectiveness of the award } & $1-4$ years & 16 & 4.2500 & .51875 & 0.644 & 0.529 \\
\hline & 5 years and more & & 4.1042 & .39779 & & \\
\hline \multirow{2}{*}{ Total } & $1-4$ years & 16 & 4.3640 & .41954 & 1.435 & 0.172 \\
\hline & 5 years and more & & 4.1034 & .31280 & & \\
\hline
\end{tabular}




\section{Discussion}

The results of the study demonstrate that since the first cycle of the SQAVW in 2011, the benefits and investment of the SQAVW in the social development of different aspects of society has been proven. In addition to this, the results show the significant role that the award plays in meeting one of its main objectives of spreading and strengthening the culture of voluntary work and showcasing its importance in social services. These results are supported by Olberding (2012) who indicated that these types of initiatives increase awareness of social needs and non-profit organizations to all people in a society.

The study aims were to determine the effectiveness of the national incentive award of the SQAVW in promoting philanthropic activities and educating people to participate effectively in various areas of social development including education. The result of the study revealed that the SQAVW has a truly significant national scope to establish basic knowledge of philanthropy in the Omani society. This knowledge will be able to assist non-governmental organizations focus on philanthropic activities by leveraging on the activities of extant groups, identifying best practices, and suggesting new areas of volunteer work and operations. These results are consistent with USAID's (2004) suggestion to explore ideas to encourage philanthropy in Muslim communities in Canada.

Upon exploring the importance of the award, it is clear that all participants indicated that the SQAVW promotes a culture of volunteerism in the social fabric of Oman. It also encourages young people to participate in volunteer work and also promotes constructive competition between voluntary institutions in a community. In general, it can be seen that this type of award is significantly important and is considered to be a backbone for raising awareness of volunteerism in the society. This deduction is supported by Olberding (2012) and Roger (2013) who outline the positive effect and power that philanthropy has to enable people and organizations to practice ethical and effective fundraising since philanthropy is voluntary. In the exploration of the importance of the award in maintaining sustainable social development, the results of the study show that the award plays a vital role in developing young people's attitudes toward the positive value of community services. It also encourages volunteer initiatives to contribute in the development process of philanthropy and develops a social awareness of others.

The study examined the importance of the award in developing people skills, and revealed that it was extremely effective in developing young people skills making them better able to manage social responsibilities. It also developed their faith through philanthropic activities. Furthermore, the award played a big role in developing people's management skills allowing them to be more capable of dealing with a crisis and increasing their problem-solving skills. The award demonstrated the value of philanthropy and allowed philanthropic work to be seen as a noble job amongst people in society. This result is supported by Roger (2013) who asserted that professional fundraising organizations play a big role in advancing philanthropic attitudes by empowering people and organizations to practice ethical and effective fundraising. This is because these stakeholders find that practicing philanthropy is incredibly powerful and is inspirational as it is entirely voluntary.

Looking at the results of the effectiveness of the award, there are many indicators that demonstrate that the participants strongly agree that it is effective. Most of them mention that the projects are innovative ideas, feel that they are useful and benefit society as a whole. They also think the projects should be administered by qualified and well trained human resources, and the projects should be beneficial for large segments of society. The results also show that this type of award guarantees the continuity of a project and is consistent with the country's sustainable development plan. Other types of indicators mentioned in the study are that the projects that deserved the awards should be able to produce added value to the national economy and should work under an authorized organization to maintain the project continuity.

\section{Conclusions}

The results of this study provides many indicators which can identify the best practices of volunteer projects and develop criteria that can be utilized in order to increase the added value of the national award for volunteers. The findings of the study indicate that the SQAVW has played a unique role in developing volunteer practices in Oman. Its criteria and conditions make people more aware and motivated about volunteer work. It also disseminates love for humanity and a sense of care towards people in society. The study results also show how the winners of the award value the importance and effectiveness of the SQAVW in terms of its reflection on individuals, people, and society.

Furthermore, the volunteer work award was created in order to support needs which haven't been met in society since it is covers 15 fields, namely economic areas, sport, social affairs, childhood, youth, charitable work, environmental projects, heritage, health, the media, educational fields, information technology, civil defense, the disabled, culture, arts, literature and women. These encompass social, environmental, educational needs, as well the lack of scarce skills in the local community. It considers volunteerism to not only help people in need, but also assist people or groups to achieve their goals, and builds self-reliance. On an individual level, it also enriches the experiences of volunteers through friendships, knowledge of themselves, provides insight into another culture, and relationships between societies. For some, it can initiate lifelong work for social change at home or abroad. 
Looking at the importance of the awards, the responses demonstrate many indicators which have been classified below:

A. The importance of the award. This includes the following indicators:

1. Indicators of the promotion of a culture of philanthropy among youths: These focus on encouraging young people to volunteer; attract new individuals to voluntary work; promote positive competition among volunteers; develop positive community service values in young people.

2. Indicators of national sense of belonging: These focus on increasing a sense of loyalty to the homeland; achieving humanitarian goals through caring for others; and activating cooperation among civil society organizations and voluntary institutions.

3. Indicators of social development: These focus on developing social responsibility values; developing a sense of faith in the individual through philanthropic actions; and inculcating noble values relating to philanthropy in the community.

4. Indicators of volunteer work management: These focus on raising a new generation who are better able to deal with a crisis and solve problems; and activate the participation of civil society institutions in the sustainable development plans of Oman.

B. The effectiveness of the award .This includes the following indicators:

1. Indicators of the project's social benefits: These focus on the project beneficiaries and the consistence with the country's sustainable development plan.
2. Indicators of projects' ideas: These focus on the projects' innovative ideas and its impact on social benefits.

3. Indicators of projects' economic efficiency: These focus on the project's value add to the national economy; the authority the project has to protect its continuity; and its cost should not over exceed the average level of project costs.

\section{Recommendations and Suggestions}

1. Foster the concept of volunteerism in the school curriculum from an early stage to increase peoples' awareness of its social return in society.

2. The award should be offered for projects that aim to serve sustainable development plan domains (health, living expenses, and education).

3. Establish a national independent association for volunteerism to pool together all NGOs to cooperate and work together. This will help organize their efforts to apply for a good project which deserves the volunteer work award.

4. Introduce the modern concept of volunteerism in to the vision and mission of NGOs through developing their activities around sustainability and the development of social services. This will help to disseminate the social and economic values of volunteerism among young people in society.

5. The volunteer award should be directed toward adding value to the social economy as well as diversifying the economy in Oman so it can overcome a national economic crisis. 
Vol.3. No.5 February, 2019, pp. 1-17

\section{Appendix}

The total Amount Raised per Charity (from 2009 - 2017) in Oman

\begin{tabular}{|c|c|c|}
\hline Organizations & No. of Donors & Amount (OMR) \\
\hline Oman Charitable Organization & 36,943 & $995,790.27$ \\
\hline Al Rahma Association for Motherhood and Childhood & 26,306 & $532,230.83$ \\
\hline Dar Al Atta'a Charity - Oman & 16,327 & $468,090.56$ \\
\hline Ministry of Endowments and Religious Affairs - Zakat Division & 1,194 & $198,665.00$ \\
\hline Omani Bahjah Orphan Society & 3,669 & $111,015.37$ \\
\hline Ghiras Charity Team & 1,922 & $45,414.99$ \\
\hline Al-Istiqaama Al-Khayriayh & 2,747 & $38,457.00$ \\
\hline Oman Cancer Association & 1,063 & $19,387.00$ \\
\hline Charity and Alms Fund - Suwaiq & 372 & $14,865.31$ \\
\hline Al Noor Association for the Blind & 682 & $13,345.00$ \\
\hline The Association of the welfare of the Handicapped & 550 & $10,292.00$ \\
\hline Assn. of Early Intervention for Children with Spl. Needs & 473 & $9,338.00$ \\
\hline Zakat and Sadaqat Fund Al- Musana & 109 & $8,641.66$ \\
\hline Oman Association for Disabled & 369 & $6,124.00$ \\
\hline Hereditary Blood Disorder Association & 449 & $5,736.00$ \\
\hline House of Funds \& Zakah - Samail & 251 & $3,260.00$ \\
\hline Oman Diabetes Association (ODA) & 118 & $2,532.00$ \\
\hline Environment Society of Oman & 209 & $2,209.00$ \\
\hline Omani Association for Elderly Friends & 139 & $2,139.00$ \\
\hline Oman Autism Association & 88 & $1,646.00$ \\
\hline Nidaa Charity & 61 & 950.00 \\
\hline Omani Association for the Hearing Impaired & 16 & 402.00 \\
\hline Oman Down Syndrome Association & 47 & 390.00 \\
\hline Manah Charity Team - Manah & 6 & 57.00 \\
\hline Oman Road Safety Association & 11 & 54.00 \\
\hline
\end{tabular}

\section{REFERENCES}

[1] Al Mutawa, O. (2015). Impact of volunteer management practice on volunteer motivation and satisfaction to enhance volunteer retention (Order No. 10093326). Available from ProQuest Dissertations \& Theses: UK \& Ireland; ProQuest Dissertations \& Theses Global. (1788102336). Retrieved from http://ezproxysrv.squ.edu.om:2082/docview/1788102336?a countid $=27575$

[2] Amaeshi, K., Bongo, M., Adi, C., Ogbechie, C. and Amao, O. O. (2006), "Corporate Social Responsibility in Nigeria: Western Mimicry or Indigenous Influences", The Journal of Corporate Citizenship, Vol. 24, pp. 83-99.

[3] Blagov, Y., \& Petrova-Savchenko, A. (2012). Corporate philanthropy in russia: Evidence from a national awards competition. Corporate Governance, 12(4), 534-547. doi:http://dx.doi.org/10.1108/14720701211267856

[4] Director General of Social Care (2017). The Sultan Qaboos Award of volunteer work $4^{\text {th }}$ cycle. Ministry of Social Development, Muscat: Sultanate of Oman.

[5] Eikenberry, A. M. (2005). Giving circles and the 
democratization of philanthropy (3175885). Available from ProQuest Dissertations \& Theses Global: Social Sciences. (305353734). Retrieved from https://search.proquest.com/d ocview/305353734? accountid $=27575$

[6] Eweje, G. (2006), "The Role of MNEs in Community Development Initiatives in Developing Countries: Corporate Social Responsibility at Work in Nigeria and South Africa," Business and Society, Vol. 45, No. 2, pp. 93-129.

[7] Geiser, C., Okun, M. A., \& Grano, C. (2014). Who is motivated to volunteer? A latent profile analysis linking volunteer motivation to frequency of volunteering. Psychological Test and Assessment Modeling, 56(1), 3-24. Retrieved fromhttp://ezproxysrv.squ.edu.om:2082/docview $/ 1519054051$ ? accountid $=27575$

[8] Hammond, R. E. (2012). Exploring the why of volunteer and philanthropic commitment at one community college: Case study of a capital campaign (Order No. 3507372). Available from ProQuest Dissertations \& Theses Global: Social Sciences. (1015380978). Retrieved from https://search.proquest.com/docview/1015380978?accounti $\mathrm{d}=27575$

[9] Hochstetler, J. J. (2014). Revising the volunteer functions inventory: An exploratory study of additional functions (Order No. 3578565). Available from ProQuest Dissertations \& Theses Global. (1502205222). Retrieved from

http://ezproxysrv.squ.edu.om:2082/docview/1502205222?a ccountid $=27575$

[10] Imbun, B. Y. (2007), "Cannot Manage without the 'Significant Other': Mining, Corporate Social Responsibility and Local Communities in Papua New Guinea”, Journal of Business Ethics, Vol. 73, pp. 177-192.

[11] Koladkiewicz, I. (2009), "Corporate social responsibility in Poland: the Responsible Business 17 Forum 2002-2007 report perspective", Social Responsibility Journal, Vol. 5, No. 1, pp. 34-47.

[12] Love, George Wesley, IV. (2009). Relationship among volunteer motivations, festival context factors, and retention of festival volunteers in the southwest (Order No. 3365605). Available from ProQuest Central; ProQuest Dissertations \& Theses Global. (305123725). Retrieved from http://ezproxysrv.squ.edu.om:2082/docview/305123725?ac countid $=27575$

[13] Micinski, N. R. (2017). The changing role of the ford foundation in international development, 1951-2001. Voluntas, 28(3), 1301-1325.

doi:http://dx.doi.org/10.1007/s11266-017-9850-4

[14] Ministry of Social Development (2017). Donation Portal for Charitable organization Sultanate of Oman Retrieved from Ministry of Social Affairs portal, retrieved 6-7-2017 from: http://www.donate.om/DonationsPortal/Home/default.aspx

[15] Ministry of Social Development (2012). Regulations of the Sultan Qaboos Prize for Voluntary Work Issued by Ministerial Decision No (128/2012). Muscat: Sultanate of Oman.

[16] Minnee, Flora and Shanka, Tekle and Taylor, Ruth and Handley, Brian. 2013. Exploring Corporate Responsibility in Oman ? Social Expectations and Practice. Social Responsibility Journal. 9 (2): pp. 326-339.
[17] National Zakat Foundation of Canada (2017). Hidaya Foundation, Zakat Foundation of America, and Sound Vision Foundation) retrieved 4-7-2017 from:

[18] Nihart, M. B. (2012). Long-term volunteer leaders in sustained positions of continuous leadership: A grounded theory study (Order No. 3524608). Available from ProQuest Central; ProQuest Dissertations \& Theses Global. (1037338202). Retrieved from http://ezproxysrv.squ.edu.o $\mathrm{m}: 2082 /$ docview $/ 1037338202$ ?accountid $=27575$

[19] Olberding, J. C. (2012). Does student philanthropy work? A study of long-term effects of the "learning by giving" approach. Innovative Higher Education, 37(2), 71-87. doi: http://dx.doi.org/10.1007/s10755-011-9189-5

[20] Payton, R. L., \& Moody, M. P. (2008). Understanding philanthropy: Its meaning and mission. Bloomington: Indiana University Press.

\section{[21] RETRIVED 4-7-2017}

[22] Roger, D. A. (2013, Nov 15). For the love of humanity. The spectator Retrieved from https://proquest.com/docview/145 8568969? accountid $=27575$

[23] Ryder, J. A. (2005). College student volunteerism: A quantitative analysis of psychological benefits gained through time spent in service to others (Order No. 3185221). Available from ProQuest Dissertations \& Theses Global. (304991173). Retrieved from http://ezproxysrv.squ.edu.om: 2082/docview/304991173? accountid=27575

[24] Saunders-Hastings, E. (2014). Private virtues, public vices: Governing philanthropy (Order No. 3627115). Available from Political Science Database; ProQuest Dissertations \& Theses Global: Social Sciences. (1558123259). Retrieved from

https://search.proquest.com/docview/1558123259?accounti $\mathrm{d}=27575$

[25] Shams Vellani, A. (2004). Philanthropy in Islam. International Charity Law Comparative Seminar Beijing, China, Oct. 12-14, p 1-6.

[26] Stein, D. D. (2011). What motivates people to volunteer? A survey research study to analyze characteristics and motives of individuals that donate time (Order No. 3491214). Available from ProQuest Central; ProQuest Dissertations \& Theses Global. (919023081). Retrieved from http://ezproxysrv.squ.edu.om:2082/docview/919023081?ac countid $=27575$

[27] Szczepanski, M.S., Geisler, R. and Sliz, A. (2009), "Building a model of corporate social responsibility in the old industrial region (in the case of Upper Silesia): a sociological perspective", Social Responsibility Journal, Vol. 5, No. 1, pp. 34-47.

[28] Trauntvein, N. E. (2011). Volunteerism at urban park and recreation agencies: Examining the role of volunteers' socio-demographic characteristics, motivations, organizational identity, and satisfaction on volunteer participation outcomes (Order No. 3483745). Available from ProQuest Dissertations \& Theses Global. (902153861). Retrieved fromhttp://ezproxysrv.squ.edu.om:2082/docview /902153861 ? accountid $=27575$

[29] USAID (2017). The Idea of Philanthropy in Muslim Contexts. The Center for Strategic and International Studies 
Vol.3. No.5 February, 2019, pp. 1-17

1800 K St., NW Suite 400 Washington, DC 20006.

[30] Vaske, A. (2008). The relationship between motivation to volunteer and cultural preference: A study of a youth development organization (Order No. 3338069). Available from ProQuest Dissertations \& Theses Global. (304836737). Retrieved fromhttp://ezproxysrv.squ.edu.om:2082/docview $/ 304836737$ ? accountid $=27575$

[31] White, M. D. (2016). Volunteer management: Understanding volunteer motivation and recognizing critical tactics for managing the volunteer workforce (Order No. 10124465). Available from ProQuest Dissertations \& Theses Global. (1807638865). Retrieved from http://ezproxysrv.squ.edu.om:2082/docview/1807638865?a ccountid $=27575$ 